\title{
Inward FDI Stock and Growth in Central and Eastern Europe
}

\author{
Lucyna Kornecki, Vedapuri Raghavan \\ Department of Economics, Finance, and Information System College of Business \\ Embry-Riddle Aeronautical University (ERAU) \\ 600 S. Clyde Morris Blvd. Daytona Beach, FL 32114, U.S.A. \\ korneckl@erau.edu, Tel: +1-386- 226-4963, fax:+1-383-226-6696 \\ ragha8d6@erau.edu, Tel: +1-386-226-6246, fax: +1-383-226-6696
}

\begin{abstract}
This article analyses the foreign direct investment (FDI) in Central and Eastern Europe (CEE) during the post communist era and tests the hypothesis that FDI contributes to the economic growth of the CEE countries. It reflects macroeconomic changes in post communist CEE and estimates the impact of the FDI stock on economic growth in the CEE using model based on the production function. This paper finds a positive association between FDI and economic growth in the CEE and a tremendous impact of FDI stock on GDP growth.
\end{abstract}

JEL Classification: P50, P51, O52, O47, P20

Keywords: Foreign direct investment (FDI), Economic growth, Central and Eastern Europe (CEE)

\section{Introduction}

The FDI inflow in the CEE economies has been a vital factor in the first stage of the privatization process during the transition period. Currently, the main reasons to pursue FDI are to boost productivity, encourage employment, stimulate innovation and technology transfer, and enhance economic growth (Mueller \& Goic, 2002). The CEE countries have identified the positive effects of FDI on the transformation process of their economies. FDI has increased in the past twenty years to become the most common type of capital flow for the reconstruction and stabilization of the CEE economies.

After the collapse of communism, central planned economies started to receive official assistance aimed primarily to support market reforms and private capital flows. Official assistance has been provided by Organization for Economic Cooperation and Development (OECD) in the form of foreign aids, grants, and loans. The private flows including foreign direct investment (FDI) and international portfolio investment (IPI) were dominated by FDI. International portfolio based enterprises are controlled domestically by local managers, as investors own a small shares of stock and have little or no influence on the management of the enterprises (Zoltan, 2002).

The inflow of FDI into the CEE countries has had an upward trend since 1990 with some minor variation. In 2003 there was a major dip in the inward FDI (USD 9,648 million). However by 2004 inward FDI had recovered and was on an upward trend reaching USD 26,764 million. The official development assistance and official aid has been quite stable across the years. The only noticeable anomalies were in 1991 (USD 3,479 million) and 1995 (USD 3,841 million). Both these years saw a sudden spike in the inflow of official development assistance and official aid. 
In recent years, there has been an increased interest in the new investment called the Greenfield investment in the CEE. For example, nearly 60 percent of Polish FDI inflows during 2006 was attributed to Greenfield investments. Poland is currently competing for Greenfield investments on export to the EU markets in the manufacturing sector (automotive, chemical, and metal investments) and in the services sector when in the past foreign investments in Poland were focused on the domestic market.

The CEE countries have increased their participation in the world economy since the fall of communism, particularly over the last few years. They accepted the challenge of trade openness and attracted significant foreign direct investment. Going global has helped them to grow faster (Cernat \& Vranceanu, 2002).

Comparison of the CEE Inward FDI Performance Index against the World Performance Index between 1988 and 2005 indicates that the Inward FDI Performance Index of CEE transitioning economies was above the world average performance index. The Inward FDI Performance Index ranks 141 countries by the inward FDI relative to the economic size of the country. The Performance Index represents the ratio of a country's share of global FDI inflows to its share in global GDP and it showed that the CEE countries received more FDI than its relative economic size.

The CEE countries increased their percentage share in the total EU trade. Between 1996 and 2003, the share of analyzed countries in the total EU trade increased from $4.5 \%$ to $7.5 \%$. The CEE share in the world GDP increased between 1996 and 2006 from $0.4 \%$ to $1.6 \%$.

This paper reviews the experiences of the CEE countries transforming from a central planning to market oriented economies, analyzes the basic economic growth trends, and the link between increasing FDI stock and the growth of real GDP. The following countries will be examined in this article: Poland, the Czech Republic, Hungary, Slovakia and Slovenia. All these countries became members of the European Union (EU) on May 1, 2004. www.eurunion.org. The EU membership has shaped major aspects of economic policies and legislation in CEE (Sohinger, 2005).

The largest economy among the countries that will be analyzed is Poland, with the population of 38.1 million. This compares to 10.4 million in the Czech Republic, 10 million in Hungary, 5.4 million in Slovak Republic, and 2 million in Slovenia www.worldbank.org.pl.

This research utilizes 1960-2006 archival data from the United Nations Conference on Trade and Development (UNCAD), United Nations Economic Commission for Europe (UNECE), World Investment Reports, as well as other selected databases.

\section{GDP and FDI in the CEE}

"The purpose of economic activity is to increase the well-being of individuals, and economic structures that are able to do so are more desirable than those that do not" (Stiglitz, 2002). There is a variety of indicators assessing transition outcomes in the CEE transforming economies. The GDP per capita constitutes a very important economic index used in the international comparisons, which shows a change in the standard of living. Increasing GDP per capita during the transformation period between 1990 and 2006 indicates rising standard of living in the CEE countries (Figure1). Since 1990, GDP per capita in all analyzed CEE countries has been increasing. In 2005, the relatively high GDP per capita has been found in Slovenia (USD 22.632) and the Czech Republic (USD 20.417), in comparison with Hungary (USD 16.994), Slovakia (USD 15.214) and Poland (USD13.791). 
There are different patterns of economic growth and differences in output performance of various CEE countries, during transition period. However, all of the transition CEE countries have been building the new macroeconomic structure via deregulation of prices, liberalization of trade, privatization, external assistance and capital market development (Paliwod, Thomas \& Farfus,

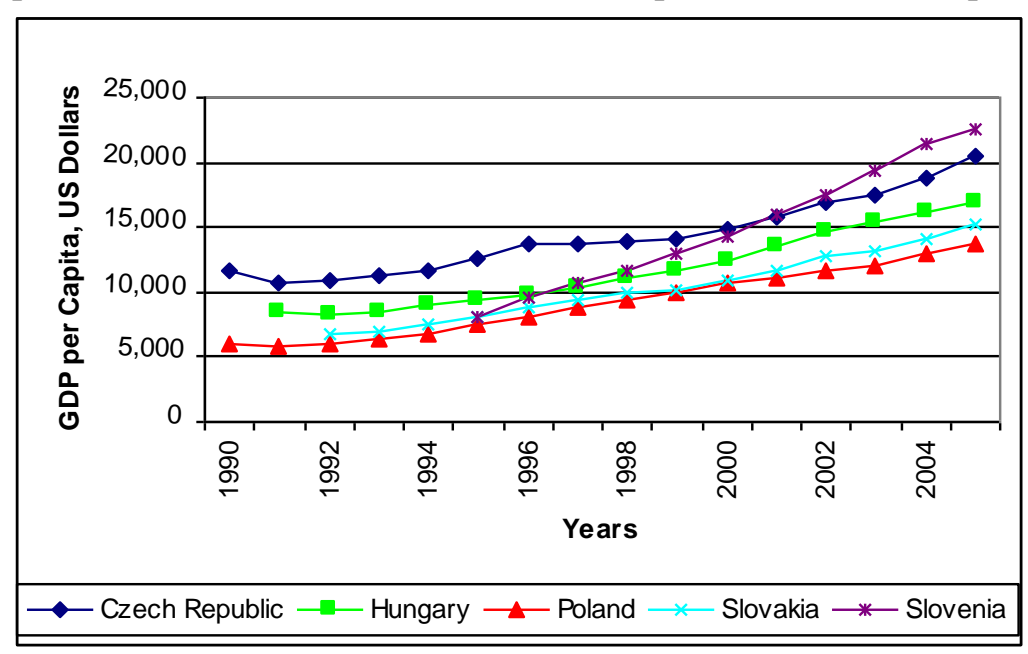
1998).

Foreign direct investment has increased in the past twenty years to become the most common type of capital flow during transition period in the CEE. The most important economic reason for attracting FDI at the beginning of the transformation process was to facilitate the privatization and restructuring of the central planning economies (Heimann, 2003). At present as the privatization and reconstructing processes come to an end, the main reason to pursue FDI is to enhance sustained economic growth (Gao, 2005).

The volume of FDI inflows has grown rapidly, as the Governments of the CEE countries have been officially encouraging FDI and developing a formal FDI promotion programs providing substantial incentives for the foreign companies. The size and increasing FDI inflows to transitioning CEE countries has been impressive. Poland, Hungary, and the Czech Republic have become the most attractive destination for foreign investments.

Important factor influencing business environment in the CEE countries is their membership in the EU. The EU policies and the national incentive based FDI policies are two driving forces influencing business environment in the CEE countries. During the preparation period of CEE countries to become members of the EU (2003-2004) the FDI inflows in the Czech Republic increased by $186.3 \%$ (from USD 1.863 to 3.596 million), in Hungary by $176.3 \%$ (from USD 1.909 to 3.365 million), in Poland by $133.7 \%$ (from USD 3.660 to 4.892 million), in Slovakia 142.1\% (from USD 636 to 904 million) and in Slovenia by 141.1\% (from USD 299 to 422 million).

Recent inflows can be attributed to the positive impact of the EU enlargement in May of 2004. For example the value of FDI located in Poland in 2006 (USD 22. 123 million) was higher by $81.9 \%$ when compared to the previous year (USD 12. 162 million). The greatest amount of FDI inflow in 2006 was invested in real estate and other business activities (USD 7. 197 million), manufacturing (USD 5.241 million), trade and repairs (USD 3.150 million), financial intermediation (USD 2.448 million), and buying and selling of real estate by nonresidents (USD 1.336 (http://www.unctad.org/Templates/Page.asp?intItemID=3277\&lang=1).

million,

The percentage share of the FDI in the CEE with regards to the countries origin indicates that the private investment from the EU countries represents the highest share of productive capacity owned by foreigners in this region. For example in Poland, the EU countries hold $74 \%$ of 
productive capacity, while the private investment originated from USA constitutes $13 \%$, in comparison with international corporations representing $6 \%$ of the foreign productive capacity (Kornecki, 2006).

New EU countries have improved the business environment and introduced policy measures aimed at liberalizing their economies. The EU reshaped conditions of doing business in the new Member States and shaped major aspects of economic policy and legislation. The statistical data on inward FDI confirm the positive reaction of FDI flow to the EU membership. The implementation of the EU policies changed the following: trade policy, competition policy, consumer protection policy, environmental policy, public procurement policy, policy towards small and medium enterprises, social policy, transport policy and socio-economic cohesion policy (Witkowska, 2000).

The EU policy towards enterprises aims to promote entrepreneurship, encourage innovation, improve competitiveness of firms, create a financial climate encouraging business activities, promotion of cooperation between enterprises. The firms can also receive assistance from the EU structural funds. Between 2007 and 2015 Poland will receive over 67 billion EUR from the EU's budget. Poland will be the largest recipient of EU funding in the coming years. The EU grants may be allocated to projects from virtually all sectors of the economy and intend to raise the economic competitiveness, among others, through transport infrastructure reform. The country's Eastern regions and the rural areas are the priority of the modernization policy for the near future (Witkowska, 2007).

Table 1. Inward FDI flow as a \% of GDP, 1990-2005

\begin{tabular}{|c|r|r|r|r|r|}
\hline Year / Country & Czech Republic & Hungary & Poland & Slovakia & Slovenia \\
\hline $\mathbf{1 9 9 0}$ & 0.20 & & 0.14 & & \\
\hline $\mathbf{1 9 9 1}$ & 2.01 & 9.04 & 0.36 & & \\
\hline $\mathbf{1 9 9 2}$ & 3.31 & 8.12 & 0.76 & 0.80 & \\
\hline $\mathbf{1 9 9 3}$ & 1.84 & 12.98 & 1.90 & 1.33 & \\
\hline $\mathbf{1 9 9 4}$ & 2.08 & 5.64 & 1.80 & 1.75 & \\
\hline $\mathbf{1 9 9 5}$ & 4.62 & 11.12 & 2.63 & 1.32 & 0.74 \\
\hline $\mathbf{1 9 9 6}$ & 2.39 & 7.11 & 2.87 & 1.76 & 0.85 \\
\hline $\mathbf{1 9 9 7}$ & 2.31 & 8.87 & 3.12 & 1.08 & 1.69 \\
\hline $\mathbf{1 9 9 8}$ & 6.10 & 6.90 & 3.68 & 3.16 & 1.02 \\
\hline $\mathbf{1 9 9 9}$ & 10.73 & 6.71 & 4.33 & 2.08 & 0.49 \\
\hline $\mathbf{2 0 0 0}$ & 9.05 & 5.76 & 5.45 & 9.42 & 0.70 \\
\hline $\mathbf{2 0 0 1}$ & 9.42 & 7.40 & 3.00 & 7.51 & 1.87 \\
\hline $\mathbf{2 0 0 2}$ & 11.87 & 4.52 & 2.09 & 16.69 & 7.34 \\
\hline $\mathbf{2 0 0 3}$ & 2.31 & 2.54 & 2.12 & 2.25 & 1.19 \\
\hline $\mathbf{2 0 0 4}$ & 4.51 & 4.57 & 5.14 & 3.00 & 2.59 \\
\hline $\mathbf{2 0 0 5}$ & 8.49 & 6.01 & 2.65 & 4.21 & 1.44 \\
\hline
\end{tabular}

Data Source: UNECE Statistical Database, Economic Statistics:

http://w3.unece.org/pxweb/Dialog/statfile1 new.asp

Calculated on the base of GDP and FDI inflow

The collapse of communism and the advanced Economic Integration of Europe shaped the global development in the twenty-first century. Analyzed CEE economies have been integrating in the global market and this process has accelerated over the past few years (De la Dehesa, 2006). 
This part of the paper focuses on the inward FDI stock as a percentage of GDP. The inward FDI flow measures the amount of FDI entering a country during a one year period, while the FDI stock is the total amount of productive capacity owned by foreigners in the host country.

The FDI inflow in transition CEE countries constitutes a relatively high percentage of GDP. The inward FDI inflow in 2005, in the Czech Republic and Hungary accounted for $8.5 \%$ and $6.1 \%$ of GDP in 2005. Poland is aiming for 5\% FDI inflow as a percentage of GDP (Table\#1).

The share of foreign stock as a percentage of GDP has been very high in Hungary, the Czech Republic, Slovenia and Slovakia, and constitutes respectively 43\%, 34\%, 24\%, and 22\% of each country's GDP (2004). In Poland, the share of foreign stock as a percentage of GDP is much lower and amounts to 19\% of GDP (Figure 2). The high percentage of foreign stock in GDP indicates that foreign capital plays a vital role in CEE economies and represents one of the most important indicators of the globalization process in CEEC.

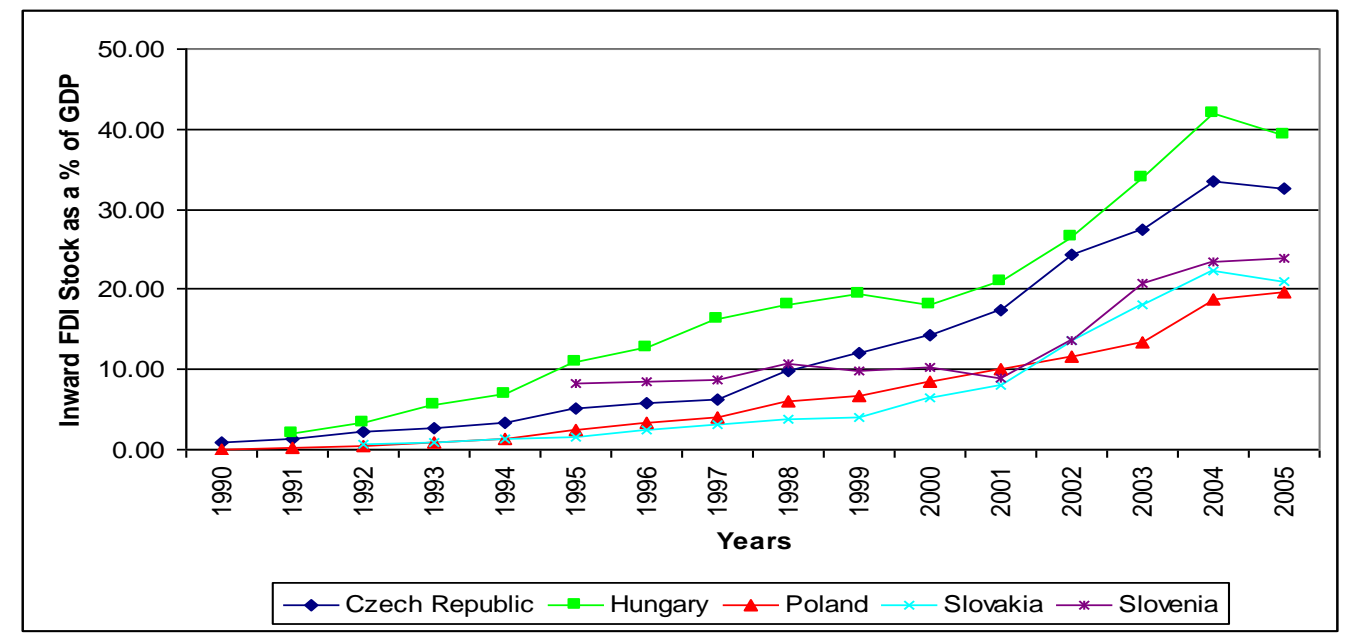

Figure 2. Inward FDI stock as a \% of GDP, CEE Comparison, 1990-2005

Source: UNECE Statistical Database and UNCTAD World Investment Report 2006

Another important indicator of the globalization process relates to an increasing export of the CEE economies in the world market. An economic globalization is based on international exchange, which leads to increase in the international trade of goods and services, movement of labor and capital (Stuart, G., 2004). The FDI demonstrates as well in higher export from the CEE. The data shows an increase in export as a percentage of GDP in the CEE economies integrating in the global market (Kornecki, 2006).

\section{Literature Review}

The available literature does not provide empirically tested evidence on the effects of FDI on economic growth in the CEE. This study examines the link between increase in FDI stock and the growth of real GDP in CEE countries and focuses on the impact of change in FDI stock on economic growth using a production function model. The results show that inward FDI stock contributes to economic growth in the CEE and constitutes an essential factor stimulating sustained economic growth.

FDI has been acknowledged as a crucial factor enhancing economic development and the standard of living in CEE. Based on references, the consensus seems to be that there is a positive 
correlation between FDI inflows and economic growth, provided that the receiving countries have reached a minimum level of educational, technological and infrastructure development (Hansen \& Rand, 2006).

The CEE countries acknowledge FDI as an essential tool in the development and modernization of their economies. An empirical neoclassical growth model reveals that foreign investment incrementally contributed to the economic transition of 27 countries in Central and Eastern Europe during the transition period 1989 to 2003 (Hartarska \& Thompson, 2008).

Benefits of FDI to the recipient economy are widely recognized. Economists emphasize the importance of FDI in fueling economic growth in CEE countries. The available literature on FDI does not yet provide empirically testable propositions on the effects of FDI on economic growth in the CEE. The analyzed model includes inward FDI stock and export as an important components of economic growth in the CEE.

In Russia, FDI appears to have been an essential force in supporting the economy during the initial chaos of transition (Brock, 2005).

Singapore and Taiwan are examples of nations outside the OECD countries that have greatly benefited from FDI and the integration in the global economy. In recent years, China and India have made remarkable progress in attracting FDI and realizing technological and economic success. A number of studies found that FDI inflows have a strong and positive effect on economic growth in China (Tian, Lin, \& Lo, 2004).

The inflow of FDI increased rapidly during the last two decades in almost every region of the world. A number of empirical studies on the role of FDI in the host countries indicate that FDI is an important source of capital, complements domestic private investment, and is usually associated with new job opportunities and enhancement of technology transfer, and boosts overall economic growth in host countries (Chowdhury \& Mavrotas, 2006).

The relationship between growing FDI stock and economic growth has motivated a voluminous empirical literature in developed and developing countries. Salehizadeh, Asheghian and others confirm the existence of a positive and significant relationship between FDI and the economic growth in the United States (Asheghian, 2004).

Our model is based on the production function concept and empirical research results that proved causality between FDI and economic growth. Researchers are using the Granger causality test to investigate the link between FDI and economic growth for the developing and developed countries. Results show that FDI does exhibit a significant relationship with economic growth: bidirectional or uni-directional (running from FDI growth to economic growth).

The relationship between FDI and economic growth in transition countries in Europe was examined using a panel data set for 27 transition economies over the period 1991-2004 as well as the methodology of panel co integration and causality tests. The empirical findings showed that foreign direct investment does exhibit a significant relationship with economic growth, at least for those transition countries that are characterized by high levels of income and have implemented successful privatization programs (http://www.springerlink.com/content/ b6q01116p4609j0j/).

Foreign direct investment, economic growth, and trade balances within the new members of the European Union was examined. The role of FDI on economic growth and trade balances of 10 emerging economies in Europe before they joined the European Union was analyzed. The Granger causality test was used to confirm the causality between FDI and economic growth (Hossein Varamini \& Svetlana Kalash, 2010).

The study was done on the causality between FDI and output in Norway and Sweeden and showed that FDI and output are causally related in the long run. Granger-causality was bidirectional in Sweden and uni-directional, running from FDI growth to economic growth, in Norway (Johan Ericsson \& Manuchehr Irandoust, 2001). 
The study on the relationship between Trade, Foreign Direct Investment (FDI) and economic growth in Greece over the period 1960-2002 used the Granger causality test and showed that there is a causal relationship between the examined variables. Economic growth, trade and FDI appear to be mutually reinforcing under the open-door policy (M. Dritsaki, C. Dritsaki \& A. Adamopoulos, 2004).

Johansen co -integration technique followed by the Vector Error Correction Model (VECM) and standard Granger causality test were employed to investigate the causal nexus between Foreign Direct Investment $(F D I)$ and economic growth in Southeast Asian Nations (ASEAN) economies (P Srinivasan, M Kalaivani \& P Ibrahim, 2010).

The empirical results from Granger causality tests based on error-correction models and the augmented level VAR suggest that there is a strong evidence of bi-directional Granger causality between FDI and economic growth for Turkey (I. Gunaydin\& E. Tatoglu, 2005).

The U.S. Bureau of Labor Statistics based on the research on a rapid inflow of foreign investment in the U.S. economy paralleled with productivity growth, suggested a positive link between the growth of productivity and foreign capital. Applying a Cobb-Douglas production function to data from 1988 to 1999, it was found that foreign capital accounted for almost $16 \%$ of overall U.S. productivity growth (Goss, Wingender\& Torau, 2007).

Asheghian and others confirm the existence of a positive and significant relationship between FDI and the economic growth in the United States (Asheghian, 2004). Asheghian examined the determinants of economic growth in the United States over time using a model based on the postulates of de Mello and found causal relationships between FDI growth and total factor productivity growth running from FDI to total factor productivity.

Salehizadeh regression estimates confirm the existence of a positive and significant relationship between FDI and US economic growth rates (Salehizadeh, 2005).

\section{Research Methodology and Regression Model}

Research methodology related to FDI and economic growth relationship in the literature has been based mostly on the production function model (Brock, 2005). The production function model investigates the relationship between labor (L), capital (K) and the economic growth, with the GDP shown as a function of labor and capital (Sawyer, 2006). Given the potential of foreign investment to add directly to the capital stock, capital $K$ in a host country is composed of domestic and foreign capital (Hartarska \& Thompson, 2008).

The theoretical framework of this study is based upon the production function model with output determined by the L (labor force employed) and K (Gross Fixed Capital Formation). In the regression model authors introduce FDI inward stock and export (X) as additional factors influencing output and productivity in the economy (Loecker, 2007). The model is using export, as inward FDI demonstrates in higher export in the developing CEE economies (Witkowska, 2007).

We use a modified Cobb-Douglas Production function (equation 1) approach based on a pooled cross section data for the sample countries for the period 1990-2006 to study the impact of inputs such as labor, capital and FDI (FDI inward stock) on economic growth. Our sample countries include Poland, the Czech Republic, Hungary, Slovakia and Slovenia. Our data is obtained from the United Nations Conference on Trade and Development (UNCTAD), United Nations Economic Commission for Europe (UNECE), World Investment Reports, as well as other selected databases. It is assumed in our model that inward FDI helps to increase capital stock in the host country which in turn increases productivity and hence the rate of economic growth. Our production-function model is explained below. 
Where:

$$
\mathrm{Y}=\mathrm{C} \mathrm{K}^{\mathrm{a}} \mathrm{L}^{\mathrm{b}} \mathrm{e}^{\log R}
$$

$$
\begin{gathered}
\mathrm{Y}=\text { Real Gross Domestic Product (GDP) } \\
\mathrm{C}=\text { Scale parameter } \\
\mathrm{K}=\text { Gross Fixed Capital Formation }(\mathrm{GFCF}) \\
\mathrm{L}=\text { Labor Force (employed) } \\
\mathrm{e}^{\log R}=\text { The rate of productivity change over time. }
\end{gathered}
$$

Rewriting (1) in terms of the rate of change over time:

$$
\overline{\mathbf{Y}}=\mathbf{a} \overline{\mathbf{K}}+\mathbf{b} \overline{\mathbf{L}}+\overline{\mathbf{R}}
$$

In our model, the productivity change $(\mathrm{R})$ is assumed to be positively influenced by both the foreign direct investment stock (FDI) and the rate of export growth (X). The productivity change defined as $\mathrm{X}$ (export) growth plus FDI growth:

$$
\overline{\mathbf{R}}=\mathbf{c} \overline{\mathbf{X}}+\mathbf{d} \mathbf{F} \overline{\mathbf{D}} \mathbf{I}
$$

Substituting equation (3) into equation (2) we have

$$
\bar{Y}=\mathbf{a} \overline{\mathbf{K}}+\mathbf{b} \overline{\mathbf{L}}+\mathbf{c} \overline{\mathbf{X}}+\mathbf{d} \bar{F} \overline{\mathrm{DI}}
$$

Where:

$$
\begin{aligned}
\mathrm{Y} & =\text { The average annual rate of growth of GDP } \\
- & \\
\mathrm{K} & =\text { The average annual rate of growth of capital (GFCF) } \\
- & =\text { The average annual rate of growth of labor force (employed) } \\
\mathrm{L} & = \\
\mathrm{X} & =\text { The average annual rate of growth of export } \\
- & =\text { The average annual rate of growth of inward FDI stock }
\end{aligned}
$$

Table 2. Results of Production Function Estimation (1993-2003)

\begin{tabular}{|c|c|c|c|c|c|}
\hline Constant & Capital & Labor & Export & Inward Stock & $\bar{R}_{A}{ }^{2}$ \\
\hdashline 2.9722 & 0.1288 & 0.6518 & 0.0514 & 0.1711 & 0.9999 \\
& $(2.760)$ & $(15.234)$ & $(1.170)$ & $(8.257)$ & \\
& & & & & \\
\hline
\end{tabular}

From Table 2 above all the examined variables except export growth are significant at the five percent level (where * over the variables denoted that they are significant at the five percent level). From the estimated coefficients we construct the sources of economic growth decomposition table for our sample CEE countries in Table 3. From this table we can see that the FDI stock shows the highest rate of growth (5.18\%) in comparison with labor (2.61\%), domestic capital $(1.03 \%)$ and export $(0.67 \%)$. FDI stock contributes $55 \%$ to GDP growth, while labor, domestic capital and export contribute respectively $27 \%, 11 \%$ and $7 \%$. These results show that the FDI as compared to other inputs such as labor, domestic capital and export has a significant influence on GDP growth in the examined CEE countries. Considering average growth of each factor, FDI and export grew 
respectively $30 \%$ and $13 \%$ when domestic capital and labor grew $8 \%$ and $4 \%$ during analyzed period of time.

Table 3. Sources of Economic Growth in CEE (1993-2003)

\begin{tabular}{|c|c|c|c|}
\hline & Growth Rate $^{\mathrm{a}}$ & Share & Average Growth Rate $^{\mathrm{b}}$ \\
\hline Factors of Production: & & & \\
\hline Domestic Capital (GFCF) & $1.03 \%$ & $11 \%$ & $8.00 \%$ \\
\hline $\begin{array}{c}\text { Labor } \\
\text { (labor force employed) }\end{array}$ & $2.61 \%$ & $27 \%$ & $4.00 \%$ \\
\hline Productivity Change: & & $7 \%$ & $13.00 \%$ \\
\hline Export & $0.67 \%$ & $55 \%$ & $30.25 \%$ \\
\hline FDI stock & $5.18 \%$ & $100 \%$ & \\
\hline Total (GDP) & $9.48 \%$ & & \\
\hline
\end{tabular}

Notes:

${ }^{\mathbf{a}}$ The numbers of this column is obtained by multiplying the estimated elasticities by the average rate of growth of the factors concerned.

${ }^{b}$ Average values of various variables (Mean values)

UNECE Statistical Database and UNCTAD World Investment Report 2006

These results show that the FDI in comparison with remaining determinants of GDP such as: labor, domestic capital and export has a significant influence on GDP growth in the examined CEE countries. This study tested the hypothesis that the FDI contributes to the economic growth of CEE countries and constitutes crucial factor stimulating economic growth.

\section{Conclusion}

During the last 15 years of the CEE economies in transition became a part of the global market and in the last six years, members of the EU. The collapse of communism and the advanced economic integration of Europe shaped the global development in the twenty-first century. The inward FDI has increased in the CEE in the past twenty years to become the most common type of capital flow.

The present paper focuses on the impact of inward FDI stock on economic growth. The analyzed aggregated model of the CEE economic growth based on the production function proves the strong impact of the FDI stock on output growth in the CEE economies and verifies the hypothesis that FDI stock, in comparison with other factors such as labor, capital and export, constitutes an essential factor of economic growth. FDI contributes immensely to the economic growth in CEE countries and constitutes a crucial factor stimulating sustained economic growth.

When interpreting regression results and planning on the future research, it is important to consider the effect of FDI on economic growth via technology. Barro and Sala-i-Martin (1999) illustrate the typical assumption of applied growth theory that foreign investment shifts technology. Examples include Blomström, Lipsey and Zejan (1992), De Gregorio (1992), and Berthelemey and Demurger (2000), (Hartarska \& Thompson, 2008). 
The new theory of endogenous growth examines the effect of FDI on economic growth via technology ( $L i \& L i u, 2005)$. Technology transfer is not limited to the industries with FDI since the new technology provided by the FDI can spread throughout the entire economy. New technology embodied in the FDI manifests itself in the form of new ideas, new products, advanced managerial skills, advanced production processes, advanced equipment and machinery, and has a positive effect on the economy (Tian, Lin,\& Lo, 2004).

There are four effects of the new theory of endogenous growth discussed in the literature: the demonstration effect (domestic firms can learn superior production technologies and management skills from foreign firms), the employment effect (foreign firms train domestic workers, who may move to domestic firms later on and bring with them updated technology knowhow and management skills), the competition effect (domestic firms are forced to update their technology and management skills due to increasing competition from foreign firms), and the linkage effect (domestic firms may learn updated technology and management skills through linkage across firms or industrial sectors). The theory of endogenous growth remains an interesting field for future research.

Acknowledgements: The authors would like to thank Henry Thompson, International Economics, the European Economic and Finance Society for his significant help and contribution to the final version of this article.

\section{References}

[1] Nicholas Apergis, Katerina Lyroudi and Athanasios Vamvakidis(2004). The relationship between foreign direct investment and economic growth: evidence from transition countries (http://www.springerlink.com/content/b6q01116p4609j0j/)

[2] Asheghian, P. (2004). Determinants of economic growth in the United States. The role of foreign direct investment. The international trade journal, 18, 1, 63-83.

[3] Brock, G. (2005). Growth in Russia during the 1990s - What role did FDI play? Post-communist economies, 17, 3:319-329.

[4] Chowdhury A., \& Mavrotas, G. (2006). FDI and growth: What causes what? The World Economy, 29(1), 9.

[5] De la Dehesa G.(2006). Winners and losers in Globalization. Blackwell Publishing. $1-8$.

[6] Melina Dritsaki, Chaido Dritsaki and Antonios Adamopoulos. A Causal Relationship between Trade, Foreign Direct Investment and Economic Growth for Greece. Department of Applied Informatics, University of Macedonia Economics and Social Sciences, Greece). American Journal of Applied Sciences 1 (3) 230-235, 2004 ISSN 1546-9239 (C) Asian Network for Scientific Information, 2004.

[7] Ihsan Gunaydin, Ekrem Tatoglu. Does Foreign Direct Investment Promote Economic Growth? Evidence from Turkey.. Multinational Business Review. Detroit: Summer 2005. Vol. 13, Iss. 2; pg. 89, 18 pgs).

[8] Gao, T. (2005). Foreign direct investment and growth under economic integration. Journal of international economics, 67(1), 157-174. 
[9] Hansen H., \& Rand, J. (2006). On the casual links between FDI and growth in developing countries. The World Economy, 29 (1), 21. Cernat, L., \& Vranceanu, R. (2002). Globalisation and development: New evidence from Central and Eastern Europe. Comparative Economic Studies, 44(4), 119-136.

[ 10] Hartarska, V.\& Thompson, H. (2008). Foreign Investment and Transition in Central/Eastern Europe along the Phase Curve. Applied Econometrics and International Development. Vol. 8-2 (2008).

[11] Kornecki, L. (2005). Role of small business development in stimulating output and employment in the Polish Economy. International Research Journal. Problems and Perspectives in Management. Ukraine, vol. 4 (1), 32-39.

[12] Kornecki, L (2005). Macroeconomic aspects of Small Business Development in Poland. Journal of the International Society of the Business Discipline (ISOBD).vol.1 (1), 1-14.

[13] Kornecki, L and Rhoades, D.L. (2007) How FDI Facilitates the Globalization Process and Stimulates Economic Growth in CEE. Journal of International Business Research (JIBR), Allied Academies.vol.3, 29-30.

[14] Kornecki, L (2006) FDI in the Polish Economy: Comparison with Central and Eastern Europe (CEE). International Research Journal Problems \& Perspectives in Management, vol. 4 (3), 5-14.

[15] Li \& Liu (2005). Foreign direct investment and economic growth: An increasingly endogenous relationship. World Development, 33(3), 393-407.

[16] Jan De Loecker. Do exports functions and productivity dynamics generate higher productivity? Evidence from Slovenia. Export, production. Journal of International Economics 73(2007) 69-98.

[17] Luiz R. de Mello Jr. ${ }^{\text {a }}$. Foreign direct investment in developing countries and growth: A selective survey. , Journal of Development studies, Volumne 34, Issue 1, October 1997.

[18] Mueller, S.L., \& Goic, S. (2002). Entrepreneurial potential in transition economies: A view from tomorrow's leaders. Journal of Developmental Entrepreneurship, 7(4), 17.

[19] Organization for Economic Co-operation and Development (OECD). (1996). Retrieved Feb. 1, 2007 from: www.unctad.org/ Templates/Page.asp?intItem $\mathrm{ID}=3146 \&$ lang=1

[ 20] Paliwoda, S.J., Thomas, M.J., \& Farfus, J. (1998). Analyzing Poland's 'tiger' economy status. European Business Journal, 10(1), 21-33.

[21] Sawyer, W.C. (2006). International Economics. Pearson. Prentice Hall. 240.

[22] P Srinivasan, M Kalaivani, P Ibrahim. FDI and Economic Growth in the ASEAN Countries: Evidence from Cointegration Approach and Causality Test. IUP Journal of Management Research. Hyderabad: Jan 2010. Vol. 9, Iss. 1; pg. 38, 26

[23] Sohinger, J. (2005). Growth and convergence in European transition economies: the impact of foreign direct investment. Eastern European Economics, 43(2), 73-94. 
[24] Stiglitz J.E. - Int'l Lab. Rev., Employment, social justice and societal wellbeing. International Labour Review, Vol. 141 (2002), No. 1 -2

[25] Stuart, G. (2004), Comparative Economic Systems in the twenty-first Centaury. $7^{\text {th }}$ Edition. New York: Houghton Mifflin Company. 186.

[26] Tian, X., Lin, S., \& Lo, V. I. (2004). Foreign Direct Investment and economic performance in transition economies: Evidence from China. PostCommunist Economies, 16(4), 499-510.

[27] United Nations Conference on Trade and Development (UNCAD). (2003). FDI Policies for development: National and international perspectives. World Investment Report. New York: United Nations. Retrieved June 2, 2007: www.unctad/wir/2003

[28] UNCTAD (2004-2006). Statistical database. World Investment Report. New York: United Nations. Retrieved June 4, 2007: www.unctad.org

[29] UNECE Statistical Database, Economic Statistics: http://w3.unece.org/pxweb/Dialog/statfile1_new.asp

[ 30] UNCTAD, Foreign Direct Investment Statistics, FDI Index, http://www.unctad.org/Templates/WebFlyer.asp?intItemID=2471\&lang=1

[31] UNCTAD Handbook of Statistics On-line / VII. Indicators of development / 7.1 Population, area and gross domestic product (1992-2004).

[32] Hossein Varaminihe, Svetlana Kalash. Foreign Direct Investment, Economic Growth, and Trade Balances: The Experience of the New Members of the European Union., Journal of East-West Business. Binghamton: Jan 2010. Vol. 16, Iss. 1.

[33] Witkowska, J.(2007), Direct Investment in the Changing Business Environment of the European Union's New Member States. Global Economy Journal.

Value 7, Issue 4, Page 11, www.bepress.com/gej/vol7/iss4/2

[34] Witkowska, J.(2000), Policy towards Foreign Direct Investors in Poland. Comparative Aspects. Economic Integration in Europe. Methodological Aspects, Wydawnictwo UL

[ 35] World Trade Organization: http://stat.wto.org/StatisticalProgram/WSDBStat ProgramHome. asp $x$ ? Language $=\mathrm{E}$

[36] World Bank Organization: http://ddpext.worldbank.org/ext/DDPQQ/ member.do? method=getMembers

[37] Zoltan Adam. Fine-tuning foreign investment: Differentiating FDI and portfolio investment in post-communist East Central Europe. Second EPIC Workshop in Florence, 2002, May 16-22. 